\section{Oldest reptile finds loophole}

\section{London}

A LEGAL loophole has opened the way to the free export of the world's earliestknown reptile fossil from Britain. The fossil was discovered in Lower Carboniferous limestones at East Kirkton, Scotland by professional fossil collector Stanley Wood, and was described in Nature $(342,676 ; 1989)$ and offered for sale. Wood's price of $£ 180,000$ caught UK museums by surprise, and a sale was agreed with the Museum fur Naturkunde in Stuttgart, West Germany. But before the sale could go ahead, the matter was brought before the Export of Works of Art Committee (Nature 342, 726; 1989), which recommended a four-month delay in the grant of an export licence.

The committee's deliberations have now proved futile on two counts. First, government lawyers ruled just before Christmas that as the fossil was a geological specimen rather than an artefact, it could not be regarded as different from any common mineral and so did not fall within the committee's jurisdiction. And, second, the Stuttgart Museum says that although it still intends to purchase the fossil it will not be able to do so until the end of March at the earliest.

The delay in the sale of the fossil should allow the Royal Museum of Scotland (RMS) in Edinburgh to present the fossil as the centrepiece of its "Dinosaurs Past and Present" exhibition, starting on 1
March. The museum is also trying to raise the money to buy the fossil.

Whatever happens to the fossil, British palaeontologists are left with the unpleasant realization that "outstanding" natural history specimens are not recognized in British law and accorded the same protection as a painting or sculpture.

Beverly Halstead of Imperial College, London, who was one of the advisers to the Export of Works of Art Committee, condemns as "ludicrous" any consideration of natural objects as distinct from and inferior to works of art in their contribution to the national heritage. After all, he says, if a fossil is just a piece of rock whose importance is conditioned by our academic appreciation thereof, a painting is simply a piece of pigmented linen.

For his part, Wood sees the current legal loophole as "very welcome to a fellow like me to get the freedom to trade freely" in fossil material. Wood says he would welcome legislation that could regulate dealing in "undoubted fossil treasures" that occurs without the knowledge of national museums. He is scathing about the apparent unwillingness of UK museums to buy his wares, despite the fact that he gives them first refusal. Ian Rolfe of the RMS says that his museum was unwilling to foot the $£ 180,000$ bill until it was shown to be the market value of the unique find. The Stuttgart offer means this has now been done.

Henry Gee

\title{
William L. Roper named as CDC director
}

\section{Washington}

THE number of top-level vacancies in US public health administration was reduced by one last week when Louis W. Sullivan, Secretary of Health and Human Services (HHS), named Dr William L. Roper as director of the US Centers for Disease Control (CDC) in Atlanta, Georgia. The position had been vacant for almost a year since former director James $\mathrm{O}$. Mason left CDC to become the Assistant Secretary of Health under Sullivan.

Roper, 41, will preside over a 1990 CDC budget of about $\$ 1,000$ million, of which almost half is set aside for work against the spread of AIDS. His appointment met with enthusiasm at CDC and in other areas of the public-health sector. He is no stranger to the public health service, having worked as an assistant state health officer in Alabama before taking up a series of important health-policy jobs at the White House. He will be leaving his present job as deputy assistant to the president for domestic policy on 1 March.

The directorship of CDC was one of several top health agency posts that the
Bush administration has not filled. Most notably, a director has yet to be found for the National Institutes of Health although James B. Wyngaarden left in August last year, and the departure of Frank Young two months ago as head of the Food and Drug Administration has created another conspicuous gap. June Osborn, dean of public health at the University of Michigan, says "this has been a delicate time for the agency [CDC] to be without permanent leadership", especially because of its important role dealing with the AIDS epidemic, and consequent rapid growth during the past few years.

Although she accepts the need for some "built-in deliberations", Osborn says that the waiting period has become too long. Howard Silver, director of the Consortium of Social Science Associations, believes that prospective candidates for senior positions are put off by low federal salaries, lengthy clearance procedures and ethical or political requirements but a spokesperson at HHS was quick to deny that candidates' views on ethical issues provide a litmus test for consideration.

\section{Tokyo}

IN an unusual reversal of roles, the United States may launch a satellite on a Japanese rocket in the mid-1990s. At the end of last month, the Japanese cabinet approved preliminary funds for a joint US-Japan project that would use a Japanese $\mathrm{H}-2$ rocket to put into orbit a satellite to monitor rainfall in tropical regions.

The Tropical Rainfall Measuring Mission (TRMM) satellite will carry microwave radiometers, an Advanced Very High Resolution Radiometer (AVHRR) to monitor visible and infrared radiation, and cross-track scanning precipitation radar, making it a "flying rain gauge" according to NASA. The satellite and radiometers will be built by the United States and the radar and launch vehicle by Japan.

Tropical rainfall is one of the more poorly understood processes involved in determining the Earth's climate. The TRMM satellite should be able to determine 30-day tropical rainfall averages over large areas with an error of 10 per cent or less after ground-based validation, according to NASA, and will provide vital information for understanding global atmospheric circulation and oceanatmosphere interactions such as EI Niño.

The budget approved by the Japanese cabinet provides $¥ 58$ million $(\$ 400,000$ ) in fiscal year 1990 for design of the interface between the satellite and rocket and between the radar and satellite. NASA began a feasibility study of the satellite last year and Katsuo Yonezawa, a senior specialist in Japan's National Space Development Agency (NASDA), is confident that both NASA and NASDA will win full support for the project.

Yonezawa says that the total cost is not clear because NASDA's H-2 rocket is still under development. But he says that Japanese newspaper estimates that it will cost each country about $¥ 20,000$ million (\$140 million) are "reasonable". If TRMM gets the go-ahead, it will join NASDA's Advanced Earth Observation Satellite (ADEOS) in orbit. ADEOS will monitor the Earth's climate and ozone layer using sensors developed by NASA, the European Space Agency and Japan (Nature 335, 486; 1988).

Launch dates for both satellites are uncertain because of the difficulties NASDA is facing in developing the new $\mathrm{H}-2$ rocket. During tests last summer the hydrogen turbopump of the first-stage liquid fuel engine shattered (Nature 340, $253 ; 1989)$ and later in the year the engine caught fire, leading to a delay of at least one year untii 1993 for the first launch of the rocket. 